\title{
Mapping trajectories of becoming: four forms of behaviour in co-housing initiatives
}

\begin{abstract}
In order learn about planning in a world increasingly characterised by resource interdependencies and a plurality of governing agencies, this paper follows the processes of becoming for two co-housing initiatives. Self-organisation - understood as the emergence of actor-networks - is the leading theoretical concept, complemented by translation from actor-network theory and individuation from assemblage theory. This theoretical hybrid distinguishes four forms of behaviour (decoding, coding, expansion and contraction) that are used to analyse the dynamics of becoming in the two cases. As a result, information is revealed on the conditions that give rise to co-housing initiatives, and the dynamic interactions between planning authorities, (groups of) initiators and other stakeholders that gave shape to the initiatives. Differences between these actors become blurred, as both try to create meaning and reasoning in a non-linear, complex and uncertain world. The paper concludes with a view on planning as an act of adaptive navigation, an act equally performed by professionals working for planning authorities and a case initiator.
\end{abstract}

Keywords: assemblages, co-housing, complexity, self-organisation, spatial planning, translation

\section{Introduction}

Diversification, decentralisation, dispersion of power and increasing resource interdependency in society (e.g. land, property, knowledge, competences, capital, authority) are posing serious challenges to contemporary spatial planners (Booher and Innes, 200I, 3; de Roo, 2010; Van Wezemael, 2012, 94; Zuidema, 2012, 2). Various planning theorists argue that this societal complexity asks for planning to acknowledge non-linearity, interrelatedness, diversity and multiplicity (Hillier, 2007; Van Wezemael, 2010; 2012; Zuidema, 2012). They turn to variegated complexity and post-structuralist theories (such as actor-network theory and assemblage theory), and elaborate on spatial planning as being entangled within a plurality of agencies, including but not limited to those of the state (Hillier, 2007: I0; Boelens, 2009; Boelens and de Roo, 2014).

A manifestation of such hybrid planning networks, characterised by resource interdependency, can be found in the practice of co-housing. Framing co-housing as private residential communities, attention has been paid to the institutional, organisational and communal features of already existing groups (Williams, 2005; Vestbro, 2010; Chiodelli and Baglione, 20I4; Chiodelli, 2015; Jarvis, 2015). By contrast, limited 
attention has been given to the way in which a community grows over time, and the interactions with other stakeholders, before the actual co-housing project is established.

A distinctive feature of co-housing initiatives is that groups of residents collectively develop their own living environments based upon their own initiative (Tummers, 20I5a). But, despite the emphasis many researchers put on the autonomy, self-motivation, self-management and bottom-up aspects of co-housing (Ruiu, 20I4; Chiodelli, 20I5; Tummers, 20I5b), co-housing projects cannot materialise without the collaboration of public authorities and other stakeholders such as landowners or financial institutions. Projects are formed through interactions and negotiations with planning authorities and other stakeholders, and simultaneously depend on the differentiated input of members. Moreover, groups are often still changing while negotiations and interactions are taking place (Tummers, 20 I ; Droste, 20I5). As such, co-housing projects are always tailor-made, specific and situational (Boelens and Visser, 20II; A., 20I5; Jarvis, 20I5; Tummers, 20I5a; 20I5b). Some authors discuss the benefits of co-housing communities for societies, and whether or not public authorities should facilitate, promote and support them - and, if so, by what measures (Chiodelli and Baglione, 20I4; Chiodelli, 20I5; Droste, 20I5). Furthermore, in order to understand the role of planning in these processes more attention should be given to the role public authorities, planning criteria and planning processes play in co-housing (Tummers, 2015a; 20I5b). But Tummers has framed planning mostly as a contextual feature: guiding principles, national policies, historical and cultural aspects, institutions (national, regional, local), legal frameworks (national, regional, local) and land-use and other functional regulators that play a beneficial or obstructive role in co-housing initiatives (Tummers, 2015b).

However, from this contextual view, planners stay at a professional distance, and, apart from the role planning frameworks play, do not have to consider themselves as actively entangled in the becoming of co-housing initiatives. This view can lead to the rather simplified statement that institutions, regulations and instruments should be changed and made more flexible to improve conditions for co-housing ( $\mathrm{Qu}$ and Hasselaar, 20II; Tummers, 20II; Droste, 20I5), although perhaps changes in attitude, communication and new governance capacities are much more important (Droste, 2015; Tummers, 2015b). Because in co-housing initiatives the hybrid and dynamic groups of initiators act like planners themselves, and planning frameworks, planning authorities and other stakeholders interact and affect the dynamics of the projects pro-actively, no a priori routines exist beforehand (Boelens and Visser, 201 I).

So, in order learn more about planning in a world of hybrid networks, resource interdependencies, undefined becomings, complexity, non-linearity and emergence, this paper follows the processes of becoming in two individual co-housing initiatives. Self-organisation - understood as the emergence of actor-networks - is taken as the leading theoretical concept, and co-housing initiatives are framed as self-organising processes of becoming. As a result, information is revealed on the conditions that 
gave rise to the co-housing initiatives, and the dynamic interactions between planning authorities, (groups of) initiators and other stakeholders that gave shape to the initiatives. As such, the paper also illustrates how notions from complexity and poststructuralist theories provide new and more elaborated understandings of planning (compare Thrift, I999; de Roo, 2010).

\section{Self-organisation as the emergence of a relational self}

\section{Two ways of understanding self-organisation}

Self-organisation, a key notion in complexity theory, is generally defined as the spontaneous emergence of order out of disorder (Prigogine and Stengers, I984; Cilliers, I998). Rich interactions between elements within a system and the system's environment, and between historic and present states of the system, lead to new order, hierarchy and closure, and to ever higher forms of complexity (Prigogine and Stengers, I984; Cilliers I998; Heylighen, 200I, I3; Teisman et al., 2009). Although boundaries of complex systems are difficult to define (Cilliers, I998, 3-5; Buijs et al., 2009, IO0), self-organisation emphasises that new emergence comes from within a system; it is spontaneous, autonomous and internally and locally driven (Cilliers, I998; Heylighen, 200i; Teisman et al., 2009).

Following this general definition, the concept of self-organisation can be applied to spatial planning in various ways - depending on the way 'systems' are understood - as existing systems that maintain or gradually change their internal structure, or as emerging networks that constitute a not-yet-existing structure (Boons et al., 2009; Klijn and Snellen, 2009; Teisman et al., 2009; Morçöl, 20Io). These two understandings are elaborated further below.

The first understanding is self-organisation as a property within complex adaptive systems. Such systems self-organise through feedback loops that either stabilise or disrupt an already existing structure (Heylighen, 200 I, 8-9; Teisman et al., 2009, I2; de Roo, 2012). This understanding has been widely applied to cities, explaining the emergence of urban form (Thrift, I999, 32). Well-known examples are found in the works of Peter Allen (I997; 20I2), Paul Krugman (I996), Michael Batty (Batty, 2005; Batty and Marshall, 20I2), Bill Hillier (20I2) and Juval Portugali (2006; 20II; 2012). These authors discuss the emergence of large-scale, macro-structures out of the interactions between individuals and collective entities. Characteristics are allocated to individual agents; these agents unintentionally create new patterns in space of which they are unaware themselves. Due to the autonomy of actors and the inability to control or oversee the dynamics that evolve from certain interventions, spatial planners only have a limited ability to steer these processes (Klijn and Snellen, 2009: 26). A distinction is made between planned and unplanned developments, and 
the latter lay out of the reach of spatial planners. When applied to the practice of co-housing, this understanding of self-organisation could provide insight in the spatial patterns that could emerge when a multitude of co-housing initiatives are taking place within a certain geographical area. The planner is meant to oversee these ongoing emergences, and intervene in the system when the outcomes head in an undesired direction. This understanding of self-organisation thus upholds a distance between professional planners and co-housing initiatives, leaving the dynamics of individual co-housing initiatives unrevealed.

The second understanding sees self-organisation as a property of emergent actornetworks. This understanding puts more emphasis on the relationships, dependencies and interactions of individual actors forming over time around specific, situated issues (de Roo, 2012, I59). This understanding resonates with the work of Gilles Deleuze (I994), Jean-François Lyotard (I984) and Jacques Derrida (I988) on the emergence of relational 'selves' (Cilliers, I998). According to Deleuze, individuals and their identity are historically constituted entities, which are not a given but are defined progressively (DeLanda, 2002, I0, 26). According to Lyotard, individuals and their identities are constructed in a complex and mobile web of meanings and relationships (Cilliers, I998, II5). According to Derrida, individuals distinguish themselves and create meaning for themselves and their surroundings by creating différance (defining the self by all that it is not), trace (remembering the absences of what has been excluded) and la même (relating to what it resembles) (Berns, 20I I). The emerging self thus never stands alone, but exists and co-evolves within a network of relationships and interactions, 'always playfully changing in an unpredictable way' (Cilliers, I998). Actor-network theory (ANT) provides an accurate way to examine and describe the emergence of such relational selves and the behaviour of their actor-networks (Callon and Latour, I981; Callon, I986; Law, I986; I992; Latour, 2005, I2).

In relation to co-housing initiatives, the second understanding of self-organisation emphasises the individual initiative, which aims at achieving or changing something, adding new activities, new uses and adding new physical objects to an existing spatial configuration. The process of self-organisation starts with a person having an idea but no co-initiators, resources or sites and moves towards a materialised project - the newly emerged order as an additional layer to existing structures, an increased multiplicity of space and place. The actor-network perspective includes human and non-human elements, both addressing people who were important in the materialisation of a co-housing initiative and planning-related factors, such as a site, architecture, planning documents, procedures, legal settings etc. This adds an explicit material and spatial understanding to self-organisation (Callon, I986; Law, I992; Thrift, I996; Latour, 2005; Thrift, 2006). The perspective of self-organisation as emergent actor-networks for co-housing initiatives opens up to an understanding of various networks which are planning simultaneously. As such, this understanding can help to overcome the distance 
between the professional planner and co-housing initiatives and reveals how dynamics, interactions and complexity play a role in the becoming of co-housing initiatives.

\section{The in-between-ness of co-housing initiatives}

Despite an initial preference for the second understanding of self-organisation (emerging actor-networks), this paper proposes a hybrid of self-organisation as a characteristic of complex adaptive systems. Notions from both actor-network theory (especially translation) and, as explained below, assemblage theory (especially individuation) are drawn upon heavily. In relation to the dynamics of co-housing initiatives, there are three major advantages of combining these theoretical notions - which share a common ground in post-structuralist ontology. First, by adding assemblage theory to the spectrum, the entanglement of the terms 'system' and 'network' are elaborated upon. Both terms address an interrelatedness of component parts that constitute a coherent entity. However, 'system' assumes a more or less fixed group, a coherent and robust entity (though open and adaptive), working together for a shared purpose within an organised set of methods and ideas (Simpson and Weiner, I989, I7:496-97). By describing a co-housing initiative as a system, the focus rests on the whole of the project - its goals, initiators, allies, location, architecture etc. - which is already assembled and is only changed because of internal interactions or the environment. Although the end result of a co-housing initiative might have these characteristics, using the term 'system' leaves the actual process of assembling - which is not at all that stable, delineated or purposeful - unattended. 'Network', on the other hand, fits far better with the fluent, transformative and open way in which co-housing initiatives emerge and with the more or less loose connections between components that only cooperate on occasions (Simpson and Weiner, I989, I0:346). But, by describing a civic initiative as a network, it seems that the group of actors remains fluent, that goals are never really achieved and keep on being adjusted to changing circumstances and that the materialisation is not the actual purpose of the initiative. Thus, neither 'network' nor 'system' fully addresses what co-housing initiatives are about.

Like systems and networks, assemblages are entities constituted from component parts with coherent interrelatedness. However, in addition to robust, purposeful systems with boundaries, an assemblage is both a whole and an open combination of heterogeneous elements (Schuilenberg, 2009). Assemblages can, but do not necessarily have to, have a well-defined identity, possess clear boundaries or a homogeneous composition - they are a continuum of relationships like networks are (DeLanda, 2006, 35; Schuilenberg, 2009, 208-9). But, in addition to 'network', assemblages bring in the notion of individuation (DeLanda, 2002) the establishment of a self or an individual entity. This self can be grouped around a matter of concern and evolve over time, making the assemblage develop in a certain direction and giving a 
certain degree of stability and regularity to the process of becoming. By combining the notions of self-organisation with networks and assemblages, the internal drivers of a co-housing initiative in its process of becoming are emphasised as well, connecting the 'self' of self-organisation to the loose and fluid interactions of an actor-network.

Secondly, this theoretical hybrid allows various forms of behaviour in processes of becoming to be distinguished. Self-organisation speaks of equilibria (long-lasting stability of a system) and bifurcations (sudden breaks of equilibria) as moments in time, and dissipation and autopoiesis as forms of behaviour (Jantsch, I980; Prigogine and Stengers, I984; Bor, I990; Luhmann, I995; Cilliers, I998; Heylighen, 200I). In assemblage theory, equilibria and bifurcations are described, but DeLanda adds the notions of coding, decoding, territorialisation and de-territorialisation as four expressive dimensions of an assemblage in its process of individuation (DeLanda, 2002; 2006). These expressive qualities, moments and forms of behaviour are described as opposites, but are not operationalised to describe the emergence of spatial initiatives such as co-housing. Translation from actor-network theory offers such an operationalisation as it speaks of four sequential steps that are taken in the formation of an actor-network: problematisation, interessement, enrolment and mobilisation (Callon, I986), or perplexity, consultation, hierarchisation and institution (Latour, 2004, Io9).

The ways in which self-organisation, individuation and translation describe processes of becoming show strong resemblances. By bringing them together, the sequential steps of translation are transformed into four forms of behaviour which are simultaneously present in the process of becoming, as interrelated movements of an assemblage over time. Whereas self-organisation addresses the internal dynamics of the system, translation and individuation focus on how the components of an actor-network or assemblage interrelate with the outside world. This paper therefore brings these different ways together in four forms of behaviour (decoding, coding, expansion and contraction), organised around axes that stabilise, destabilise, individualise or de-individualise the emerging actor-network (see Figure I). Together, these forms of behaviour can be used to reveal how an emerging actor-network of a co-housing initiative deals with reasoning and intervening in a non-linear and uncertain world; how hybrid networks are constituted; and how resource interdependency is dealt with.

Thirdly, this theoretical hybrid resolves the question of intentionality. As the actornetworks of co-housing initiatives are intentionally created for a specific (community) interest, it is difficult not to see their materialisation as a linear and predictable process. However, the newly emerged order of a materialised co-housing project is not the result of one actor summoning others, but a complex constitution of time-specific and place-specific conditions and actors sharing drivers and ideas. The 'self' of the initiative is not defined beforehand, but formed along the way, becoming more detailed and known over time. Elements in the environment become included or excluded as the 


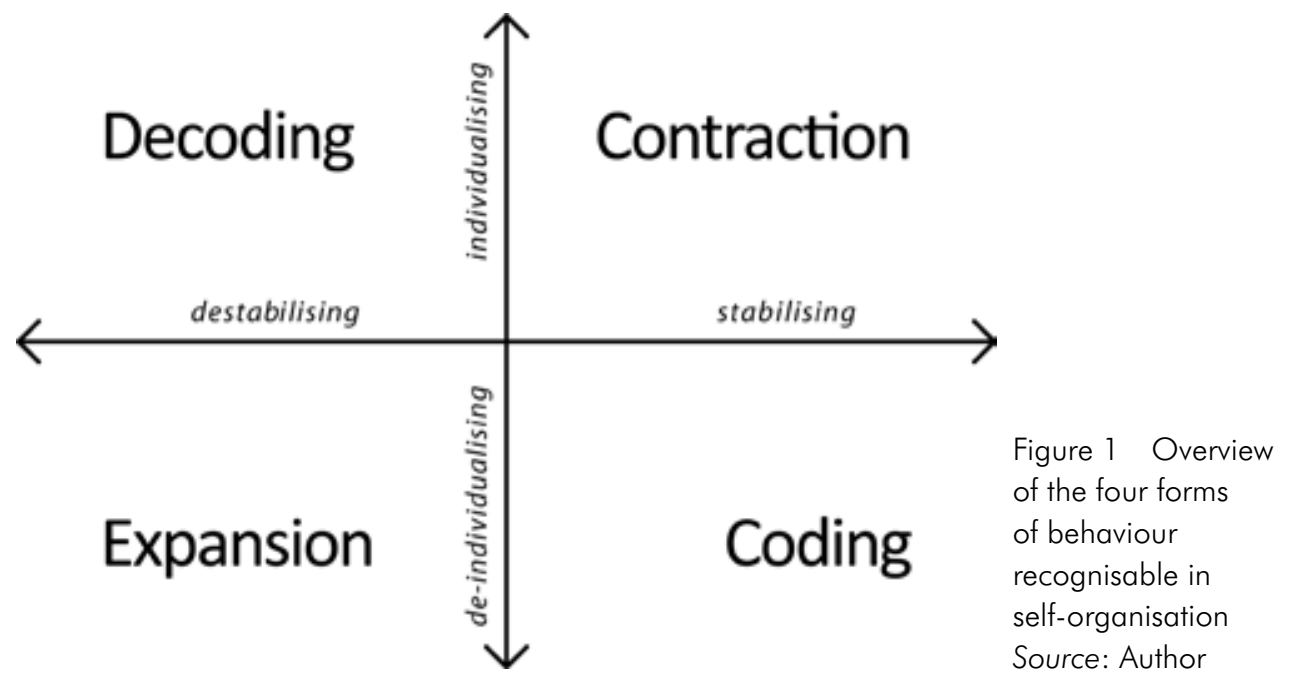

initiative strives for a fit between its 'self' and its environment, and aims at organising a context in which it can further expand and actualise its 'self'.

The notion of translation sheds light on how intentionality plays a role in this form of self-organisation. Translation concerns the process of making connections between things that gain consistency along the way, a process-ordering equivalent to self-organisation. Translation can be both intentional and collateral. Intentional translation is the sequence of proactive, purposeful and deliberate actions in order to establish something envisioned, the intentional process of network building (Mol, 2002; Latour, 2004; Law, 2009b). Collateral translation happens incidentally and unintentionally along the way, and often remains unquestioned and uncontested - for instance, when actors accidently encounter in space or when a person without intention provides orderings by telling others how he or she sees things (Law, 2009a).

Co-housing initiatives show features of both intentional and collateral translations. Regardless of whether the initiative has an idealistic motive or a personal, individual interest, there always is a reason why the initiators came up with their idea. These initiators are proactive interventionists, working hard to assemble the necessary resources around their idea, which is their collective driver. During the process of becoming, initiating actors cannot oversee what complex and non-linear encounters will further shape or undermine their initiative. Moreover, the eventual physical intervention is hardly ever entirely envisioned in the shape of a fixed plan. And people in the initiative might not know exactly where and how they will end up, or how the spin-off of their initiative may turn out, as many collateral translations can happen too during its process of becoming. The theoretical hybrid thus explains how a process of becoming is full of intentional and collateral translations, and how a co-housing initiative can be purposeful and non-linear at the same time. 


\section{Tracing the processes of becoming of two co-housing initiatives}

\section{Introduction of the cases}

Two eco-villages in the Danish countryside were traced and mapped as examples of co-housing initiatives. The cases, Fri og Fro and Hallingelille, were deliberately chosen from a wider set of co-housing initiatives due to their resemblances in character and size and differences in planning processes. Case data was collected to provide multiple case study analysis (Yin, 1984) and included: observation during field visits, document analysis (reports, newsletters, proposals, websites, political documents, statutory instruments) and interviews with key players (initiating residents and local planning authorities). Interviewees were asked to give their chronological description of the process towards materialisation of the initiatives.

Fri og Fro (FF) is an eco-village based on social, economic and environmental sustainability principles in the municipality of Odsherred, north-west of Sjælland. The first ideas for an eco-village came from an initiating couple who started to collect a group of co-initiators in $200 \mathrm{I}$ and 2002. After a period of searching for locations and elaborating on their core values, a location was found in Egebjerg and negotiations with the municipality of Odsherred took place in 2003-04. The municipality was willing to cooperate with the initiators and changed the original planning frameworks as the initiative was seen as a means to bring new life to the declining village. As the municipality did not have the resources to rewrite the local legal plan themselves, they asked the initiators to do so. In 2005, the land was officially purchased and the people of Fri og Fro moved in. Then the building of seventeen individual houses, the communal facilities and landscaping started, which took several years. Houses were self-built with natural and reused materials. Some elements of the core values defined in the beginning did not materialise, especially those concerning communal living and ownership - as the individual building activities and the architectural diversity undermined the sense of community. Through local amenities, such as the school and the shop, and informal interactions, the community of Fri og Fro and Egebjerg became socially intertwined (Elm and Dilling-Hansen, 2003; Martinussen, 20I0; Interview Kommune, 20II; Interview Residents, 20II; Website Fri og Fro, 201 I).

Hallingelille (HL) is an eco-village in the municipality of Ringsted, mid-Sjælland. In 1994, the first idea was formed, and it became more focused when in 1998 the initiators defined core values based on sustainability, permaculture and consensus democracy. Under the name 'Village 2000', the programme requirements were set (IOO houses in the countryside, with amenities for children and the elderly). On various sites planning approval was sought during the years i999-200. However, the programme requirements appeared to be too demanding for local planning frameworks and the trajectory became locked in local planning disputes. This made a reframing of the 
original ideas of Hallingelille necessary. During the years 2002-05, a site in Ringsted was eventually found where the county allowed for a pilot to adjust planning frameworks. However, the local villagers of Valsømagle opposed the eco-village, the existing legal plan remained in place and the eco-village was adjusted accordingly. Thus, a major part of the initial idea did not materialise. The clearing of the grounds and the building of eighteen individual houses took place from 2005 to 2010 . Two plots from the twenty available remained undeveloped. Owing to the attention given to individual building activities, the communal aspect of the eco-village had gradually been losing importance, and a visioning process on living together in the eco-village was organised in 20II. The outcome of this visioning process was a governance framework that did not demand consensus any more, but allowed for more internal diversity. Gradually, the original hostility between the village of Valsømagle and Hallingelille dissolved and the eco-village became a showcase for sustainability in the municipality (Elm and Dilling-Hansen, 2003; Interview with resident A HL, 20I3; Interview with resident B HL, 20I3; Website HL, 20I3; Interview with Kommune Ringsted, 20I4).

In the following section, an analysis is made of how various forms of behaviour were manifested in these cases (see also Figures 2 and 3).

\section{Decoding}

A first form of behaviour recognisable in self-organisation, individualisation and translation is disassociation from existing schemes and a desire to move in a new direction. In self-organisation, such behaviour is described as 'bifurcation', the spontaneous and sudden breaks of an existing structure (Cilliers, I998; Heylighen, 200I). In translation, such behaviour is described as problematisation or perplexity, which defines a new state to move to, a problem to be solved, a challenge to take forward (Callon, I986; Latour, 2004) - in the form of a 'lightning strike' - like an event or a decision, a choice or a rejection of a certain situation (Thrift, 2000). In assemblage theory this movement is described as 'decoding' (DeLanda, 2006).

In the becoming of the eco-villages, decoding was performed in the following ways.

- By the initiators at the start of the initiative. They decoded from the way they lived before, by making a deliberate choice for a distinct lifestyle and a do-ityourself planning and building process. They decoded from conventional building methods as they made the deliberate choice to build their houses with reusable and renewable materials and experiment with new sustainable building techniques.

- By the initiators in the course of their planning process, in relation to core values and intentions defined in the beginning. In Hallingelille, original plans were abandoned as these appeared unfeasible within existing planning frameworks. 


\section{Fri og Fro}

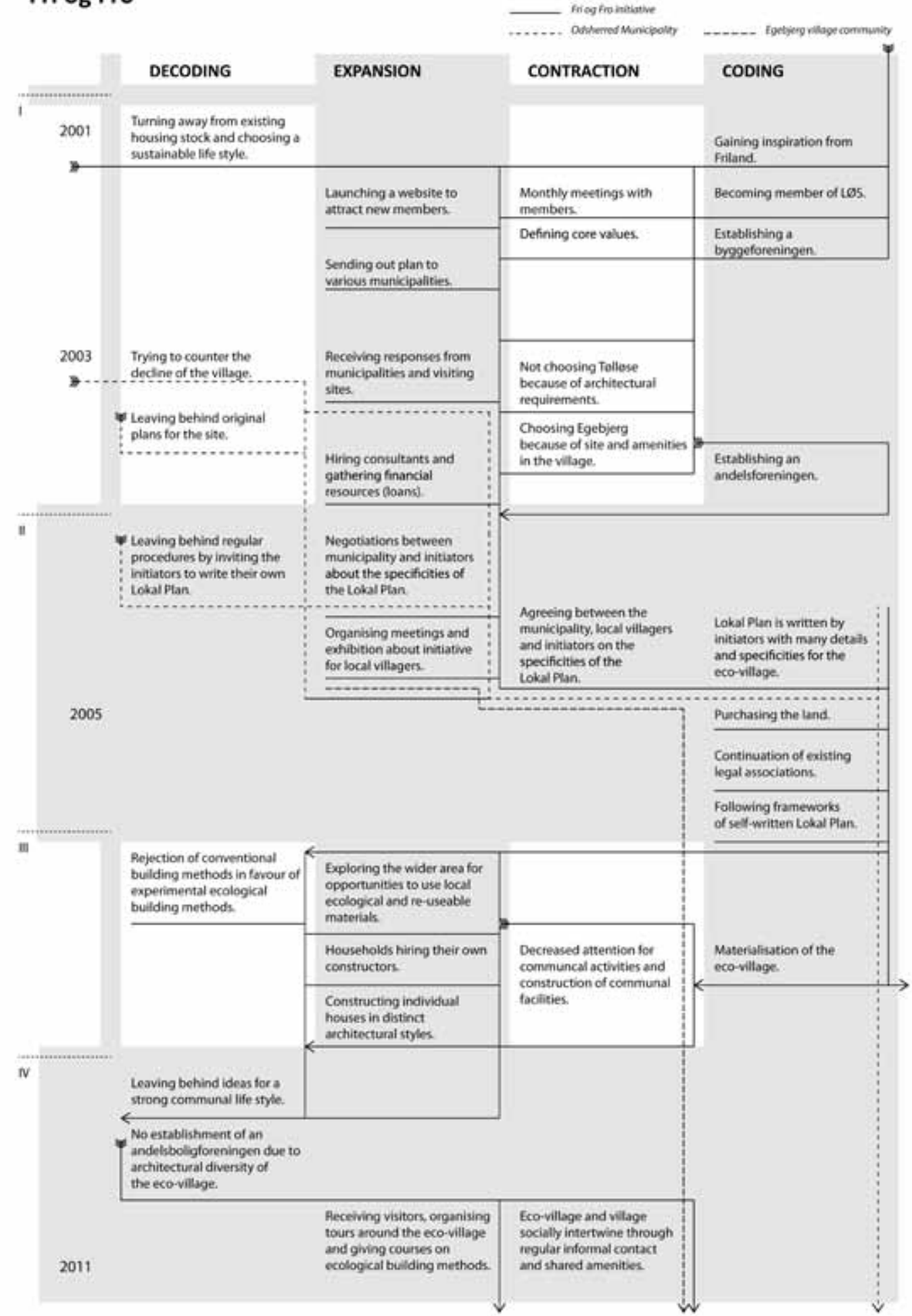

Figure 2 Fri og Fro: chronological overview of the four forms of behaviour. Source: Author 


\section{Hallingelille}

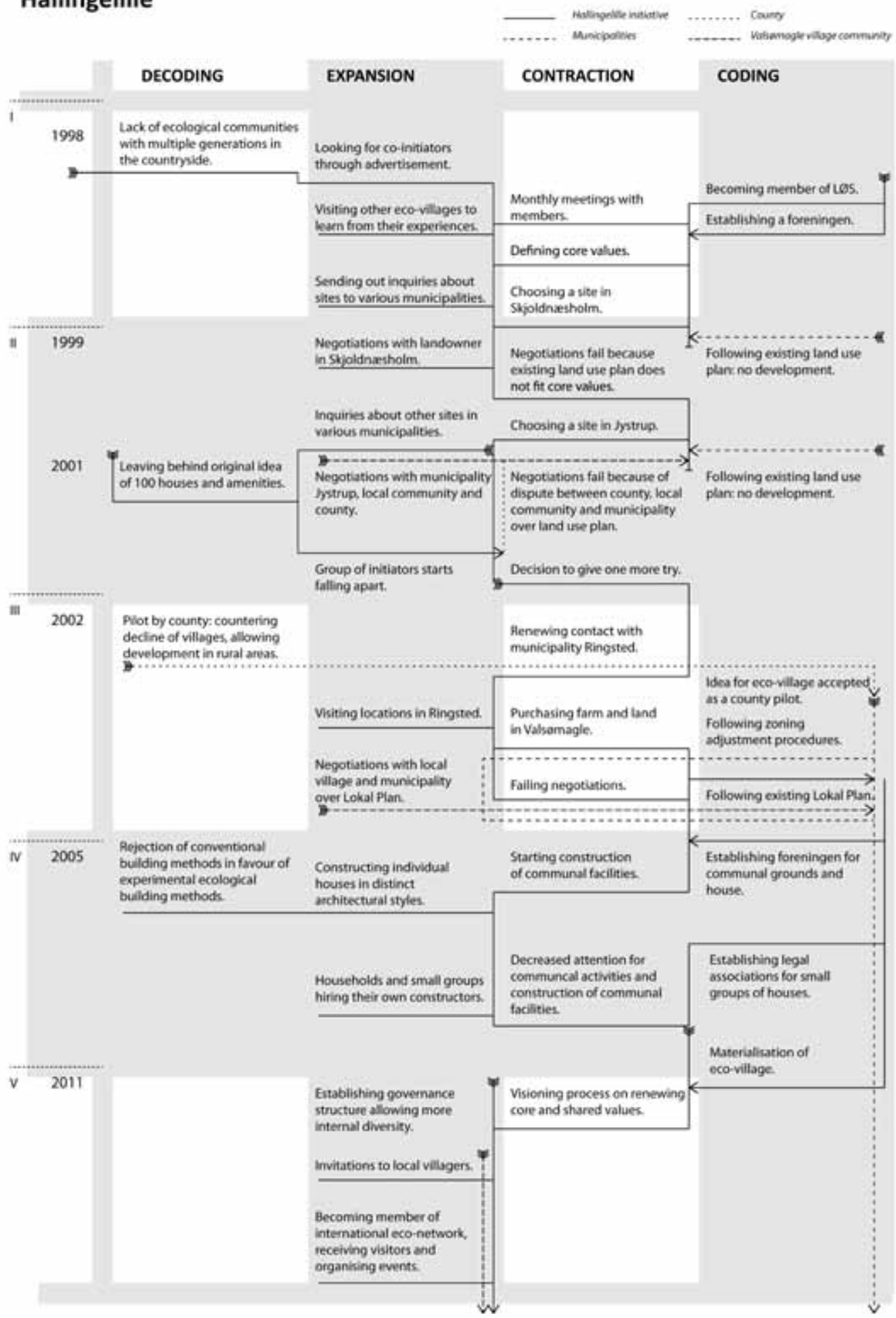

Figure 3 Hallingelille: chronological overview of the four forms of behaviour. Source: Author 
When individual building activities undermined the collectiveness of the eco-villages, Hallingelille decoded from the original idea of consensus democracy, and Fri og Fro decoded from the original idea of communal ownership.

- By planning authorities involved in the initiatives. In Fri og Fro, Odsherred municipality had envisioned a development of 6o houses, but eventually agreed on the development of only i7 houses, and slightly changed the boundaries for rural and urban areas. The municipality was willing to do this as the site had been for sale for decades and the village was in decline. The municipality also decoded from their usual way of working when they asked the initiators to write their own legal plan. In Hallingelille, a new community for soo dwellings in rural land was an unconventional thing, which only became negotiable when the county introduced a decoding of regulations with a pilot which allowed for development adjacent to villages suffering from demographic decline.

In this analysis, decoding revealed the conditions that motivated the initiators to turn in a new direction - mainly a lack of sustainable and communal living environments in the countryside. Around these concerns, actor-networks were formed including the members of the initiatives and public planning authorities intended to decode from stagnated local planning conditions and demographic decline of the villages. The analyses of decoding also showed how original ideas and goals were left behind by the initiators, due to external forces or unforeseen developments within the initiative itself.

\section{Coding}

A second form of behaviour refers to the way in which an initiative becomes familiar, obvious, something common that fits existing schemes in the outside world. Due to this behaviour, the initiative grows heavy with externally recognised norms that make the initiative stable, fixed and strong. In translation, such behaviour is described as becoming a 'black box' (Callon, I986; Latour, 2004) - or becoming part of already existing black boxes to gain externally derived stability. In self-organisation, this behaviour can be understood as the emergence of an equilibrium. In assemblage theory this behaviour is described as coding: smoothing the trajectory of the initiative by following already existing codes (DeLanda, 2006).

In the becoming of the eco-villages, coding was performed in the following ways.

- By the initiators in relation to earlier experiences and already existing eco-villages and co-housing projects. The initiators brought in personal experiences and professional knowledge to which they coded in order to be trusted by planning authorities and other professionals they encountered. Other eco-villages and co-housing projects offered inspiration, created references and offered lessons learned. Both Fri og Fro and Hallingelille became members of the national association of eco-villages (Landsforeningen for Økosamfund), and applied 
some of the core values found in other initiatives to their own. Once materialised, Fri og Fro and Hallingelille provided such coding to other initiatives too.

- By the initiators in relation to legal forms of association. Both initiatives established (various) foreningen (associations) to structure their internal discussions, provide membership, organise collective loans, collectively purchase land and maintain collective amenities such as sewage systems, communal grounds and communal houses.

- By the initiators and the local planning authorities, in relation to legal local plans and regular planning procedures. In Denmark, land use is separated into rural areas, nature conservation areas and urban areas (in which housing is allowed). If a municipality or landowner intends to change these boundaries, local residents will have to agree. For both initiatives such a zoning adjustment was necessary. In Fri og Fro, regular procedures were followed and only small adjustments were made to the existing legal plan. Moreover, the initiators of Fri og Fro used the legal plan as a way to add, and formalise, their own specific requirements to the eco-village, making the plan much more specific than a regular municipal plan. In Hallingelille, earlier sites proved to be heavily coded by planning frameworks that prohibited an eco-village of that size. Even in Valsømagle, where a countyinitiated pilot allowed for a divergence of these procedures, the local planning authorities eventually decided to hold to the existing legal plan anyway - including its architectural and functional demands - and forced the initiators to do so too.

In this analysis, the behaviour of coding revealed the conditions to which the initiative conformed and the legal frameworks and (planning or institutional) routines that were followed. This coding could happen either by external force or by a selfmotivated act to become 'recognised'. Sometimes, the codes developed by the initiative itself were even more demanding and specific than the local planning codes. Coding also reveals what was learned from the case and what became normal and repeatable. Overall, the conditions found in the field of coding were deployed to give stability and security to the initiatives.

\section{Expansion}

A third form of behaviour refers to a widening orientation of the initiative, an opening of boundaries, exposure and exploration of new content. This behaviour is about creating diversity, connectivity and redundancy of plans, ideas, content and actors - trying to be as broad, informed and open for new and different options and actors as possible. In selforganisation, this behaviour is described as 'dissipative' (increasing diversity) (Cilliers, I998; Heylighen, 200I; B. et al., 20I3), in actor-network theory as 'interessement' (making people pay attention to the emergent network) and in assemblage theory as 'de-territorialisation' (scattering the network over various locations and increasing diversity) (DeLanda, 2006). 
In the becoming of the eco-villages, expansion was performed in the following ways.

- By the initiators to recruit members. This happened in the form of websites, advertisements and informal inquiries between acquaintances. When the building activities started, internal diversity increased architecturally and socially in both initiatives, and the focus on communal life diminished. As a result, both initiatives decided on a governance structure that allowed such internal diversity.

- By the initiators, at the beginning of the process, towards municipalities in order to find a site suiting the demands of the initiative. This was done by sending out project plans to various municipalities, inquiries among land owners, and from field trips to possible sites.

- By the initiators of Fri og Fro towards the local village community, to inform them about the initiative and to organise support for adjustments to the land use plans, in the form of a meeting and exhibition of the plans at the local school of Egebjerg. Individual households searched for left-over and reusable building materials in the surrounding area, and thus interacted with other building projects as well. In Hallingelille expansion towards the local village community mainly aimed at overcoming hostility and resistance, which decreased once the decision was made to stay within the boundaries of the existing legal plan.

- By the initiators in order to collect information, knowledge and expertise necessary for the planning and building process. This happened in the form of meetings with other eco-villages, and consultations with constructors, banks, architects, legal advisors. Both initiatives acknowledged that these external advisors were easiest to work with if they already had some experience in sustainability and co-housing. Once materialised, both Fri og Fro and Hallingelille passed on their experiences to others, in the form of guided tours, building courses and international eco-village events.

In this analysis, expansion revealed how the initiators explored different options and deployed favourable conditions (including local planning frameworks), how they gathered the necessary resources for their initiatives and how they sought support and supporters. Sometimes this happened on a temporary basis (consultants, contractors, other eco-villages), sometimes on a permanent basis (site and municipalities, local communities, members of the initiative). Expansion also brought the initiative into contact with like-minded actors and embedded the initiative in a local environment. Most expansion happened intentionally, although some collateral events were part of the expansion too (finding like-minded actors, internal diversification). 


\section{Contraction}

A fourth form of behaviour in processes of becoming is a closing off, a narrowing down through selecting, explicating and consolidating content, stabilising existing actor constellations or even reducing the number of actors involved. In self-organisation this is described as 'autopoietic behaviour': self-reproduction, a strengthening of boundaries and exclusion of otherness, the setting of internal hierarchy and order, and an articulation of boundaries through choosing representation, a selection and sorting process (Luhmann, I995; Cilliers, I998; Heylighen, 200I; B. et al., 2013). In assemblage theory this behaviour is described as 'territorialisation' (DeLanda, 2006) and in actor-network theory as 'enrolment' (Callon, I986; Latour, 2004). This paper uses the term 'contraction'.

Contraction explains how the initiative is stabilised internally, what choices are made, how the identity, the binding principles and boundaries are maintained and what organisational form is chosen. Activities are focused on confirmation, strength, homogeneity and maintenance, bringing into alignment, cementing links and binding a group together.

In the becoming of the eco-villages, contraction was performed in the following ways.

- By the initiators - socially (in the form of common dinners, annual parties, work weekends to maintain the communal facilities and grounds) and for the organisation of their internal decision-making process (in the form of meetings, appointing spokespersons, choosing core values). Decisions were made on financing, sewage systems, local plans, playgrounds, landscaping and communal houses. These decisions did not always hold, as unforeseen developments (the inability to come to a decision with a local community or the increased diversity due to individual building activities) undermined this contraction again. Whereas in Fri og Fro some initial decisions (such as fixed prices) became neglected, in Hallingelille a new process of contraction was initiated once the building activities had finished, in the form of a visioning process on collective living.

- By the initiators and the municipalities concerning the site of the eco-village. The initiators chose a site that fitted best with their ideas and wishes from the offers received from municipalities and landowners. In Fri og Fro a matching site was found relatively soon, whereas Hallingelille had to go through negotiation processes several times. Next, contraction focused on the negotiations between the municipality and future landowners on a new legal local plan. In Fri og Fro these negotiations ran smoothly for reasons found in decoding and expansion. In Hallingelille, however, negotiations eventually did not lead to an agreement on a development as envisioned by the initiators, so, eventually, by contraction, it was decided to scale down the initiative considerably. Only then was a match found between a site and the initiative, at the costs of the original plans and ideas. 
- By the initiators towards the local communities. In Fri og Fro, the initiators easily created sympathy among the local community (see expansion). Conflicts over nuisances during the building activities were solved informally, the local village community was invited to Fri og Fro events and the communities socially intertwined, with children going to the same school. For Hallingelille, however, negotiations between the initiative and local residents repeatedly proved problematic. On an earlier site, the initiative became entangled in a planning dispute between the county on one side and the municipality and the local community on the other side, and, despite negotiations and adjustment of the plans (fewer dwellings and facilities), the landlord decided not to sell the land after all. When farmland was found and bought next to the small village of Valsømagle, the initiative met with hostility and opposition from the local village community again, and no adjustment to land use boundaries were made. Only over time, once building activities were finished, did hostility decrease and the eco-village and existing village communities start to interact a bit more.

In this analysis, contraction showed how the initiatives gained internal strength and external legitimacy through a continuous process of making choices, agreeing and formalisation. Contraction of the initiative led to a clear formulation of ideas and plans, crucial in establishing associations with municipalities, local communities and contractors. But, as soon as choices were made, people left the initiative and others joined, based on decisions made so far. The relation between intentional and collateral contraction was the same as in expansion: most of the contraction was intentionally performed to move towards materialisation of the initiative, whereas unexpected events or encounters either undermined earlier contraction or challenged the initiatives to perform additional contraction.

\section{Conclusions}

The aim of this paper was to learn more about planning in a world of hybrid networks, resource interdependencies, undefined becomings, complexity, non-linearity and emergence. Co-housing initiatives were taken as an example. Instead of focusing on internal, social aspects of these communities, discussing their benefits for society, or framing planning as merely contextual, this paper focused on the dynamics within the emergence of individual co-housing initiatives. For this purpose, four forms of behaviour were distinguished, based on the notions self-organisation, translation and individuation. As a result, information was revealed on the conditions that gave rise to the co-housing initiatives and the dynamic interactions between planning authorities, (groups of) initiators and other stakeholders.

Conditions that gave rise to the initiatives were found in the fields of coding and decoding. In a simplified interpretation of these behaviours, one could conclude that 
decoding revealed contextual features that became intrinsic drivers, set the initiatives in motion and made it unique and different (e.g. lack of certain forms of housing, desire for a distinct lifestyle). Coding revealed the contextual features to which the initiators had to comply - for instance, legal frameworks for collective action, planning frameworks or building codes. From such a reading, again the professional distance of planners in relation to co-housing initiatives remains intact. However, when taking a closer look at the behaviours in both cases a much more complex picture becomes visible.

Coding also emerged from the initiative itself, in the form of plans, regulations, references to earlier experiences and other projects. This gave certainty and stability to the initiative, made initiators well prepared, experienced and educated, turned the initiative into something common and made the initiators and other stakeholders believe they could achieve their goals. Coding is thus not something reserved for professional planners. Similarly, with decoding, this is not solely reserved for the co-housing initiators. In the field of decoding, conditions were also found that made planning authorities and local communities willing to experiment, turn away from the usual ways of doing things and adapt to meet the changes envisioned by the initiatives. These conditions were stagnating local spatial developments or demographically declining villages. The cases thus show how contextual features and intrinsic drivers from the initiators, planning authorities and local (village) communities become entangled with one another in the processes of becoming.

\section{Planning as navigation}

And there is more. In both cases, all four forms of behaviour were performed more or less simultaneously, and none of the behaviours was dominant. Moreover, these behaviours were performed equally by the initiators, planning authorities and local (village) communities. These actors did not necessarily share or agree with the goals of the co-housing initiative, but rather interlocked their own interests into the projects - and thus made them move forward as well. As co-housing initiators usually do not have all the resources available needed to materialise their initiative, they spend a considerable effort in collecting them, such as land, property, knowledge, procedural and legal competences, funding, investment capital, authority and key positions within networks. It became evident from the cases that the actors who contribute greatly to the collection of resources were people who were able to establish connections. They were very well aware of their own self-interest and perspectives, capable of relating that self-interest to other actors and organisations, able to guide actions in a certain direction and willing to create conditions in favour of the intentions of the emerging actor-networks. The term 'navigator' would suit these actors: people heading for a certain end goal, but in a complex and every changing environment, and without known or fixed paths and destinations adapting (Hillier, 20 I I). 
In the becoming of a co-housing initiative these navigators have two major roles. First, they have to know, use and deploy legal settings, locations and other factors of importance, and try to find a fit between the initiative and the environment. In other words, they have to combine and find workable associations between the conditions that can cause a decoding and conditions that allow for a certain coding. Secondly, these navigators continuously perform a balancing act between expansion and contraction. They have to keep the network of the initiative fluent for a long time in order to be as flexible and adaptive to new or changing conditions as possible in a process of expansion. At the same time, they have continuously to keep an eye on the initial goals, and seek recognition, support, solidification and certainty, and generate internal strength and coherency in a process of contraction.

In a complex, dynamic and non-linear world, the role of planners is not just to create contextual features such as planning frameworks or guidelines, nor solely to focus on institutional change. Instead, planning becomes an act of navigating, equally performed by professional planners working for planning authorities as well as other civic initiators and stakeholders involved in the cases. All are proactively engaged in the emerging networks of public, private and civic actors, navigating through local, legal, institutional and spatial conditions, and continuously deploying and redefining the conditions at hand. All have to be continuously adaptive to changing circumstances. In a world full of hybrid networks, resource interdependencies and undefined becomings, distinctions between professionals working for planning authorities and the case initiators thus become blurred, as both try to create meaning and reasoning in a non-linear, complex and uncertain world.

\section{References}

ALLEN, P. M. (1997), Cities and Regions as Self-Organising Systems: Models of Complexity, Amsterdam, Gordon \& Breach Science.

ALLEN, P. M. (2012), 'Cities: The visible expression of co-evolving complexity', in J. Portugali, H. Meyer, E. Stolk and E. Tan, (eds), Complexity Theories of Cities Have Come of Age: An Overview with Implications to Urban Planning and Design, Berlin, Springer-Verlag, 67-89.

BATTy, M. (2005), Cities and Complexity: Understanding Cities with Cellular Automata, Agent-based Models, and Fractals, Cambridge, MA, MIT Press.

BATTY, M. and MARSHALL, S. (2012), 'The origins of complexity theory in cities and planning', in J. Portugali, H. Meyer, E. Stolk and E. Tan, (eds), Complexity Theories of Cities Have Come of Age: An Overview with Implications to Urban Planning and Design, Berlin, Springer-Verlag, 2 I-46. BERNS, G. (20I I), 'Jacques Derrida', in B. Ieven, A. Van Rooden, M. Schuilenburg and S. Van Tuinen (eds), De nieuwe Franse filosofie: denken en thema's voor de 2Ie eeuw, Amsterdam, Boom, 93-II2.

Boelens, L. (2009), The Urban Connection: An Actor-Relational Approach to Planning, Rotterdam, Uitgeverij ого. 
BOELENS, L. and VISSER, A.-J. (20 I I), 'Possible futures of self-construction: post-structural reflections on ten years of experimentation with (C)PG', in L. Qu and E. Hasselaar (eds), Making Room for People: Choice, Voice and Liveability in Residential Places, Amsterdam, Techne Press, IO3-28.

BOELENS, L. and DE ROO, G. (2014), 'Planning of undefined becoming: first encounters of planners beyond the plan', Planning Theory, doi: Io.I I77/I4730952I4542631.

BOOHER, D. E. and INNES, J. E. (200I), Network Power in Collaborative Planning (IURD Working Paper Series), Institute of Urban and Regional Development, University of California at Berkeley, http://escholarship.org/uc/item/2mm27omp.

BOONS, F., VAN BUUREN, A., GERRITS, L. and TEISMAN, G.R. (2009), 'Towards an approach of evolutionary public management', in G. R. Teisman, A. van Buuren, and L. Gerrits (eds), Managing Complex Governance Systems: Dynamics, Self-Organisation and Coevolution in Public Investments, New York, Routledge, 23 ${ }^{-}{ }^{-50}$.

BOR, J. (I990), 'Bergson en de onmiddelijke ervaring' (PhD thesis), Leiden University, Amsterdam, Boom.

BUIJS, J.-M., ESHUIS, J. and BYRNE, D. (2009), 'Approaches to researching complexity in public management', in G. R. Teisman, A. van Buuren and L. Gerrits (eds), Managing Complex Governance Systems: Dynamics, Self-Organisation and Coevolution in Public Investments, New York, Routledge, 37-55.

CALLON, M. (I986), 'Some elements of a sociology of translation: domestication of the scallops and the fishermen of St Brieuc Bay', in L. John (ed.), Power, Action and Belief: A New Sociology of Knowledge, London, Routledge \& Kegan Paul, i96-233.

CALLON, M. and LATOUR, B. (I98I), 'Unscrewing the big Leviathan: how actors macrostructure reality and how sociologists help them to do so', in K. Knorr-Cetina and A. Cicourel (eds), Advances in Social Theory: Towards an Integration of Micro- and Macro-sociologies, London, Routledge \& Kegan Paul, 277-303.

CHIODELLI, F. (2015), 'What is really the difference between cohousing and gated communities?', European Planning Studies, doi: Io.1080/og654313.2015.Iog69I5.

CHIODELLI, F. and BAGLIONE, V. (2014), 'Living together privately: for a cautious reading of cohousing', Urban Research and Practice, 7, 20-34.

CILliers, P. (I998), Complexity and Postmodernism: Understanding Complex Systems, London, Routledge.

DELANDA, M. (2002), Intensive Science and Virtual Philosophy, London, Continuum.

DELANDA, M. (2006), A New Philosophy of Society: Assemblage Theory and Social Complexity, London, Continuum.

DELEuZE, G. (1994), Difference and Repetition, London, Continuum.

DERRIDA, J. (I988), Limited Inc., Evanston, IL, Northwestern University Press.

DE ROO, G. (2010), 'Being or becoming? that is the question! confronting complexity with contemporary planning theory', in G. de Roo and E. A. Silva (eds), A Planner's Encounter with Complexity, Farnham, Ashgate, 19-38.

DE ROO, G. (2012), 'Spatial planning, complexity and a world "out of equilibrium": outline of a non-linear approach to planning', in G. de Roo, J. Hillier and J. Van Wezemael (eds), Complexity and Planning: Systems, Assemblages and Simulations, Farnham, Ashgate, I41-76. 
DROSTE, C. (2015), 'German co-housing: an opportunity for municipalities to foster socially inclusive urban development?', Urban Research \& Practice, 8, 79-92.

ELM, A. and DILLIG-HANsEN, T. (2003) (eds), Økosamfund i Danmark, Galten, Landsforeningen for Økosamfund.

HEYLIGHEN, F. (200I), 'The science of self-organisation and adaptivity', in L. D. Kiel (ed.), Knowledge Management, Organizational Intelligence and Learning, and Complexity, Oxford, The Encyclopedia of Life Support Systems (EOLSS), Eolss Publishers Co. Ltd.

HILLIER, B. (2012), 'The genetic code for cities: is it simpler than we think?', in J. Portugali, H. Meyer, E. Stolk and E. Tan (eds), Complexity Theories of Cities Have Come of Age: An Overview with Implications to Urban Planning and Design, Berlin, Springer-Verlag, I29-52.

HILliER, J. (2007), Stretching Beyond the Horizon: A Multiplanar Theory of Spatial Planning and Governance, Farnham, Ashgate.

HILLIER, J. (20I I), 'Strategic navigation across multiple planes: towards a Deleuzean-inspired methodology for strategic spatial planning', Town Planning Review, 82, 503-27.

JANTSCH, E. (I980), The Self-organizing Universe: Scientific and Human Implications of the Emerging Paradigm of Evolution, Oxford, Pergamon Press.

JARVIS, H. (20I5), 'Towards a deeper understanding of the social architecture of co-housing: evidence from the UK, USA and Australia', Urban Research E Practice, 8, 93-I05.

KLIJN, E.-H. and SNELLEN, I. (2009), 'Complexity theory and public administration: a critical appraisal', in G. R. Teisman, A. van Buuren and L. Gerrits (eds), Managing Complex Governance Systems: Dynamics, Self-Organisation and Coevolution in Public Investments, New York, Routledge, $17-36$.

KRUGMan, P. R. (I996), The Self-Organizing Economy, Oxford, Blackwell.

Latour, B. (2004), Politics of Nature: How to Bring the Sciences into Democracy, Cambridge, MA, Harvard University Press.

LATOUR, B. (2005), Reassembling the Social: An Introduction to Actor-Network-Theory, New York, Oxford University Press.

LAW,J. (I986), 'On the methods of long-distance control: vessels, navigation and the Portuguese route to India', in J. Law (ed.), Power, Action and Belief: A New Sociology of Knowledge?, London, Routledge \& Kegan Paul, 234-63.

LAW, J. (I992), 'Notes on the theory of the actor-network: ordering, strategy, and heterogeneity', Systems Practice, 5, 379-93.

LAW, J. (2009a), Collateral Realities, version of 29 December 2009, available at http://www. heterogeneities.net/publications/Law2oogCollateralRealities.pdf.

LAW, J. (2009b), The Greer-Bush Test: On Politics in STS, version of 23 December 2009, available at http://www.heterogeneities.net/publications/Law20ogTheGreer-BushTest.pdf.

Luhmann, N. (I995), Social Systems, Stanford, CA, Stanford University Press.

LyOTARD, J.-F. (I984), The Postmodern Condition: A Report on Knowledge, Manchester, Manchester University Press.

MARTINUSSEN, P.V.(20IO), 'Self-grown sustainability: a study of private initiatives in sustainable urban planning' (unpublished Master's thesis), Copenhagen, University of Copenhagen Faculty of Life Sciences.

MOL, A. (2002), The Body Multiple: Ontology in Medical Practice, Durham, NC, Duke University Press. 
MORÇÖL, G. (20I0), 'Issues in reconceptualizing public policy from the perspective of complexity theory', Emergence: Complexity and Organization, I 2, 52-6o.

PORTUGALI, J. (2006), 'Complexity theory as a link between space and place', Environment and Planning $A, \mathbf{3}^{8}, 647-64$.

PORTugali, J. (201 i), Complexity, Cognition and the City, Heidelberg, Springer.

PORTUGALI,J. (2012), 'Complexity theories of cities: achievements, criticism and potentials', in J. Portugali, H. Meyer, E. Stolk and E. Tan, (eds), Complexity Theories of Cities Have Come of Age: An Overview with Implications to Urban Planning and Design, Berlin, Springer-Verlag, 47-66.

PRIGOGINE, I. and STENGERS, I. (I984), Order Out of Chaos, London, Heinemann.

QU, L. and HASSElaAR, E. (eds) (2011), Making Room for People: Choice, Voice and Liveability in Residential Places, Delft, Techne Press.

RUIU, M. (20I4), 'Differences between cohousing and gated communities: a literature review', Sociological Inquiry, 84, 316-35.

SCHUILENBERG, M. (2009), 'Assemblages', in E. Romein, M. Schuilenberg and S. van Tuinen (eds), Deleuze Compendium, Amsterdam, Boom, 205-23.

SIMPSOn, J. and WEINER, E. (eds) (1989), The Oxford English Dictionary, Second Edition (20 vols) Oxford, Oxford University Press.

TEISMAN, G. R., VAN BUUREN, A. and GERRITS, L. (2009), Managing Complex Governance Systems: Dynamics, Self-Organisation and Coevolution in Public Investments, New York, Routledge.

THRIFT, N. (1996), Spatial Formations, London, Sage.

THRIFT, N. (I999), 'The place of complexity', Theory Culture Society, r6, 3I-69.

THRIFT, N. (2000), 'Afterwords', Environment and Planning D: Society and Space, 18, 213-55.

THRIFT, N. (2006), 'Space', Theory Culture Society, 23, 139-46.

TUMMERS, L. (20I I), 'Self-managed co-housing: assessing urban qualities and bottlenecks in the planning system', in L. Qu and E. Hasselaar (eds), Making Room for People: Choice, Voice and Liveability in Residential Places, Delft, Techne Press, I53-76.

TUMMERS, L. (2015a), 'Introduction to the special issue: towards a long-term perspective of self-managed collaborative housing initiatives', Urban Research \& Practice, 8, I-4.

TUMMERS, L. (20I5b), 'Understanding co-housing from a planning perspective: why and how?', Urban Research \& Practice, 8, 64-78.

VAN WEZEMAEL, J. E. (20I0), 'Urban governance and social complexity', in G. de Roo and E. A Silva (eds), A Planner's Encounter with Complexity, Farnham, Ashgate, 283-308.

VAN WEZEMAEL, J. E. (2012), 'Transformative practice as an exploration of possibility spaces', in G. de Roo, J. Hillier and J. E. Van Wezemael (eds), Complexity and Planning: Systems, Assemblages and Simulations, Farnham, Ashgate, 93-II3.

VEstbro, D. (ed) (2010), Living Together: Co-Housing Ideas and Realities around the World, Stockholm, Royal Institute of Technology, Division of Urban Studies, in collaboration with Kollektivhus NU.

WILLIAMS, J. (2005), 'Designing neighbourhoods for social interaction: the case of cohousing', Journal of Urban Design, ro, 195-227.

YIN, R. (1984), Case Study Research, Beverly Hills, CA, Sage.

ZUIDEMA, C. (2012), 'Post-contingency - making sense of decentralization in environmental governance', (PhD thesis), University of Groningen. 
Interview with Kommune Odsherred (22 March 2011).

Interview with Kommune Ringsted (30 June 20I4).

Interview with Resident A HL (I6 May 20I3).

Interview with Resident B HL (I6 May 20I3).

Interview with Resident FF (22 March 2011).

Website Fri og Fro, 20II: www.friogfro.dk (accessed 7 September 201 I).

Website Lange Eng, 20II: www.langeeng.dk (accessed I2 March 20II). 